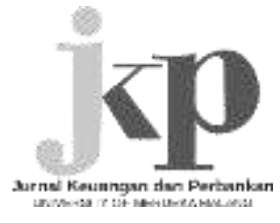

\title{
The Determinants of Manufacturing Firms' Transfer Pricing Decisions in Indonesia
}

\author{
Badingatus Solikhah ${ }^{1 *}$, Deni Dwi Aryani ${ }^{2}$, Anna Kania Widiatami ${ }^{3}$ \\ 1,2Accounting Department, Faculty of Economics, the State University of Semarang, Indonesia \\ ${ }^{3}$ Economic Education Department, Faculty of Economics, the State University of Semarang, \\ Indonesia \\ ${ }^{*}$ Corresponding Author: badingatusbety@mail.unnes.ac.id
}

\begin{abstract}
The purpose of this study is to analyze the influence of tunneling incentives, corporate governance mechanisms, foreign operations, bonus mechanisms, and debt covenants toward transfer pricing. This study compares two proxies for transfer pricing variables: Related Party Transaction Asset and Liability (RPTAL) and Transfer Pricing Intensity (TPI). Manufacturing companies that have transactions with foreign related parties are employed in this study. The researchers purposively selected the Panel data from 24 companies in the period 2014 - 2018. There were 120 units analyzed using panel data regression. The research shows that transfer pricing practice via asset and liability transactions (RPTAL) and related parties receivables transaction is relatively high. The difference in the scope of measurement with the RPTAL and TPI causes differences $n$ the study results in model 1 and model 2. Model 1 showed tunneling incentives, foreign operations, and debt covenants proved to have a significant positive effect. In model 2 , it is found there is a positive association between tunneling incentives and transfer pricing.
\end{abstract}

Keywords : Transfer Pricing; Corporate Governance Mechanism; Foreign Operation; Bonus Mechanism; Debt Convenant

JEL Classification : G30, G41

\section{INTRODUCTION}

Trade access through the World Trade Organization (WTO) triggers individual firms' growth into multinational corporations penetrating the global market share. Multinational firms are also associated with foreign direct investment in cross-border transactions; therefore, they have policies that impact social and economic growth (Nguyen, 2019). These innovations are the basis for deciding transfer pricing between related companies. According to the principle of fairness and business practice, companies should carry out transfer pricing policies known as the arm's length principle. The arm's length principle would compare transactions in independent companies to distribute income for the transactions between related parties.

Taxes are closely associated with investment goals, so it is necessary to choose an investment location from a region. Multinational companies use transfer pricing between 
related companies to provide revenue for affiliated companies with different tax rates (Cristea \& Nguyen, 2016). Many multinational companies register transactions with transfer pricing using two different reports, one for management accounting and one for tax reporting (Robu \& Căpățină-Verdeș, 2017). Amidu et al. (2017) reported that multinationals are expanding their income by maximizing global profits and minimizing global taxes by taking affiliates into low tax rate countries and tax-haven countries. Tax avoidance positively affects business earnings, with many firms carrying out international transfer pricing (Nguyen, 2019).

Companies benefit from the international transfer pricing system in many ways. Transfer pricing mechanisms are often used to minimize import duties and income taxes in connection with international trade with related parties (Armstrong et al., 2015). The primary function of transfer pricing manipulation is to shift profit and to determine and estimate the profitability of all business entities in each division of tax compilation (Robu \& Căpățină-Verdeș, 2017). Additionally, profit accounting in a country with high tax rates effectively reduces the tax by overstating the import price while understating the export price, which effectively reduces the Group's tax rate (Borge et al., 2018). The government subjectively considers tax avoidance to be one of the transfer pricing objectives in companies (Mispiyanti, 2015).

Regulations on transfer pricing are implemented in the state tax system by incorporating rules created by the State to ensure companies comply with each country's tax mechanism and legal system (Rathke, 2016). Considering numerous adverse effects of transfer pricing, tax authorities in each country are increasingly strict in monitoring transfer pricing by imposing sanctions, adding new necessary records, adding details, training audit personnel, inspections, and specialist officers (Holtzman \& Nagel 2014). Transfer pricing by different parties in Indonesia is assumed to influence the tax rate so that the Indonesian tax rate does not yield the maximum results (Rosadi, 2019). Solikhah and Suryarini (2020) claim that taxes play a very significant role for economic growth in Indonesia because taxation is the primary income source to finance state expenditures, even the source of State income from taxes over the last ten years varies between 70 and $80 \%$ of the overall State revenue in the APBN (The State Revenue and Expenditure Budget) (Solikhah dan Suryarini, 2020). However, the realization of tax revenues was always below the target and displayed a downward trend, as shown in Figure 1.

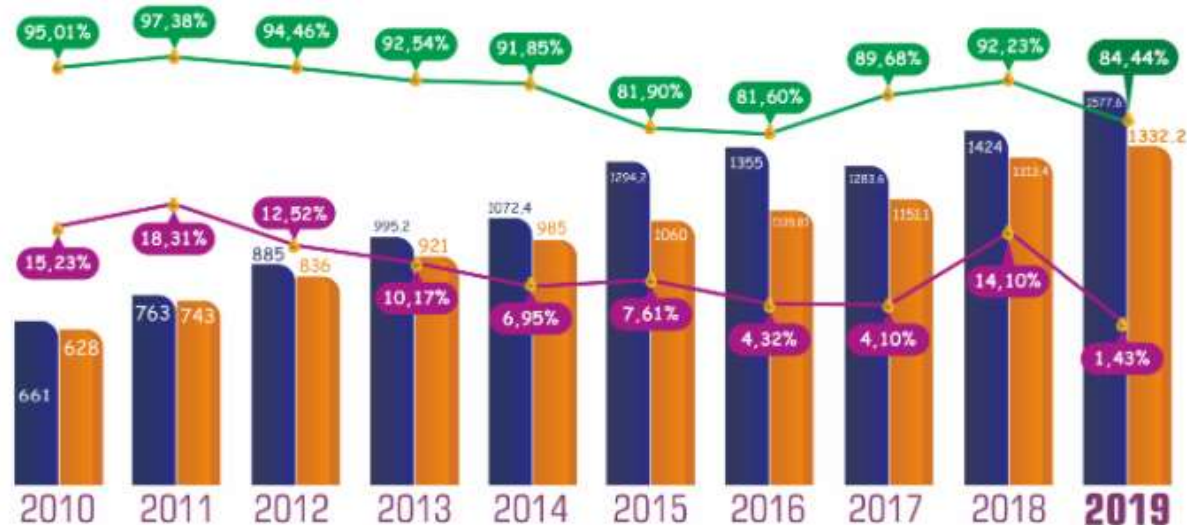

Tax Revenue Target (IDR Trillion)

Realization of Tax Revenue (IDR Trillion)

Tax Revenue Achievement on the State Revenue and Expenditure Budget (APBN)

Growth (yoy)

Figure 1.Target and Realization of Tax Revenues in Indonesia in 2010-2019 Source: Directorate General of Taxes (2019) 
Nguyen (2019) suggests that transfer pricing may reduce potential tax revenues from the government's perspective. The shift of corporate profits from high tax countries to low tax countries could impact the tax burden that companies should pay. The more these mechanisms are applied, the less tax revenue the state can produce. In Indonesia, tax collections declined in a row between 2014 and 2016, 1,072 trillion, 1,294 trillion, and 1,355 trillion. In 2017-2018, the tax revenue grew by 1,737 trillion and then by 2,007 trillion in sequence. The Ministry of Finance had promoted increased tax achievement in Indonesia by promoting taxpayers, law enforcement, and synergies between agencies, but the goal was not achieved.

Several previous researchers have examined transfer pricing to avoid taxes by analyzing factors that correlate with non-optimal tax efficiency. A study from Tang (2016) found that tunneling incentives positively impact tax avoidance. This study is, however, inversely related to research by (Nazihah et al., 2019). Besides, Pratama (2020) found that corporate governance mechanism has a negative impact on transfer pricing. The findings of this analysis differ from those of (Noviastika et al., 2016). International transactions' positive effect on transfer pricing by using foreign ownership has been proved (Pratama, 2020). In the meantime, a study by (Yulia et al., 2019) investigating the international ownership relationship produced the opposite outcome. Research by Nazihah et al. (2019) has revealed a positive impact on the bonus mechanism's transfer pricing decisions, which contrasts to Susanti \& Firmansyah's study (2018). Merle et al. (2019) research shows that debt covenant positively impacted the price of transfers, which is not consistent with Indrasti's study (2016).

Research by Utama (2015) and Suryarini et al. (2020) from Indonesia have measured the existence of such relationships using a Related Party Transaction of Assets and Liabilities (RPTAL), while research by Merle et al. (2019) from France using Transfer Pricing Intensity (TPI). The RPTAL will analyze assets and loans of related parties while TPI explores only a part of corporate assets, such as the related party receivable. Cheung et al. (2009) found that companies acquiring assets from related parties tend to pay higher prices than fair transactions in arm's length transactions. By comparison, companies that sell assets in related parties tend to be paid for less than fair transactions in arm's length transactions (Utama, 2015). Both the RPTAL and TPI measurements indicated a transfer of assets to associated parties, which play a pivotal role in transfer pricing to avoid tax aggressively. However, besides an indication of an asset transfer, the RPTAL measurement also indicates improper debt determination. Setiawan (2014) suggested that debt-related transactions are included in transactions manipulated for transfer pricing to conduct tax avoidance.

This study was carried out based on the research gaps and the phenomenon gap shown in the inconsistency between the analysis results of the variables and Indonesia's incapacity to achieve the tax target. Differences in variable measurement, differences in research objects, and differences in data analysis tools are presumably responsible for these findings' inconsistencies. Therefore, this study aims to compare the two-variable transfer pricing measures and analyze companies from the Indonesian stock exchange listed in the manufacturing sector using the panel data regression analysis. This study aimed to examine the impact of the tunneling incentives, corporate governance mechanism, foreign operation, bonus mechanism, and debt covenant on the Indonesian manufacturing companies' alleged transfer pricing on the Indonesia Stock Exchange. This study was innovative in terms of incorporating the use of transfer price intensity (TPI), aligned with a study by Merle et al. (2019), as Cheung et al. (2009) thought that companies with asset acquisitions from related parties appear to issue higher price payments than fair 
transactions in arm's length transactions. By comparison, companies selling assets to associated parties tend to earn lower rates than fair transactions subject to arm's length transactions (Utama, 2015). To the best of the writer's knowledge, no previous study has been performed in the best possible way to compare measures using two indicators of the dependent variables.

This analysis's dependent variables use two different variables: the associated party asset and responsibility transaction (RPTAL) as model 1 and Price strength (TPI) as Model 2. The independent variables, including foreign operations and corporate governance mechanisms, with an estimation of the proportion of Commissioners' board in transfer pricing, are rarely investigated. Transfer pricing variables measured with two measures, such as RPTAL and TPI, should provide an overview of the interaction between the independent and dependent variables in model 1 and model 2.

\section{HYPOTHESES DEVELOPMENT}

Tunneling was initially used to describe the acquisition of a non-controlling shareholder in the Czech Republic by using a transfer of assets and income for controlling shareholders (Noviastika et al., 2016). This controlling party is the parent company under which a group is regulated. Local governments and private businesses are more likely to tunnel their licensed subsidiaries (Hu \& Sun, 2019). The Agency's theory can explain how disputes emerge because of divergent priorities between management and shareholders (Jensen \& Meckling, 1976). Research by Tang (2016) indicates that tunneling incentives have a substantial positive impact on tax avoidance. Besides, research from Azzura \& Pratama (2019) and Nuradila \& Wibowo (2018) has shown that tunneling incentives have a major impact on Indonesia's transfer pricing. While the business becomes a public enterprise, the group's influence is still significant (Susanti \& Firmansyah, 2018). Because in Indonesia, firms have consolidated shareholding and broad company influence tunneling for transfer pricing, can be easily enforced. The bigger the tunneling incentive, the more aggressively transfer pricing is carried out using RPTAL and TPI.

\section{$\mathrm{H}_{1}$ : Tunneling incentive has a significant positive effect on transfer pricing through measure of RPTAL. \\ $\mathrm{H}_{2}$ : Tunneling incentive has a significant positive effect on transfer pricing through measure of TPI.}

A good corporate governance mechanism has a significant role in protecting investors from opportunistic actions (Tang, 2016). Good governance can also create a good reputation and improve investors' trust (Widyasari et al., 2019). Managers prefer to avoid taxation on personal income and disregard demands from stakeholders (Sofiati \& Zulaikha, 2018). Managers also introduce many tax evasion schemes leading to revenue losses (Amidu et al., 2017). Thus, companies prefer to pay extra expenses under the business's supervision (Jensen \& Meckling, 1976). Research by Pratama (2020) shows that the mechanism for corporate governance using the commissioners' board's proportion has a significant adverse effect on transfer pricing.

Managers are not taking opportunistic actions under supervision of the commissioners' board (Sofiati \& Zulaikha, 2018). Yendrawati \& Asy'ari (2017) reported that corporate governance mechanisms could resolve management action based on agency theory. One of the opportunistic acts, known as tax aggressiveness, is a transfer pricing. A good governance company is careful in all activities, particularly activities that can worsen the company's image by violating regulations. Profitable governance corporations are vigilant to carry out practices that may exacerbate the companies' reputation by breach of 
laws. Transfer pricing implementation can be evaluated using related party transactions of assets and liabilities (RPTAL) and transfer pricing intensity (TPI). Effective corporate governance has been proven to reduce the negative impact of related party transactions (El-Helaly, 2018). It means that the better the quality of the corporate governance mechanism by the proportion of board members of Commissioners', the more transfer pricing through RPTAL and TPI can be prevented.

\section{$\mathrm{H}_{3}$ : Corporate governance mechanism has a significant positive effect on transfer pricing through RPTAL. \\ $\mathrm{H}_{4}$ : Corporate governance mechanism has a significant positive effect on transfer pricing through TPI.}

Business strategy has a significant impact on export activities from foreign market operations (Falahat \& Migin, 2017). Davies et al. (2016) revealed that multinational corporations shift profit to other countries under the guise of exporting, and most go to tax havens countries. For this cause, the transfer pricing is directly related to tax avoidance. The relationship between managers as agents and shareholders as principals is found in agency theory (Jensen \& Meckling, 1976). Multinational firms in Denmark have demonstrated that transfer pricing was exploited to gain additional revenues (Cristea \& Nguyen, 2016). The relationship between the manager as the agent and the shareholders as the principal is found in agency theory (Jensen \& Meckling, 1976). Research by Pratama (2020) on foreign operations using the foreign share ownership proportion proves the positive and significant effect on transfer pricing.

The larger the shareholding of foreign controlling shareholders, the greater their power in deciding the company's decisions. Septiyani et al. (2018) reported that foreign controlling shareholders could sell products from companies they own to other privatelyowned companies at prices below market prices. The transfer pricing can be evaluated through related party transactions of assets and liabilities (RPTAL) and transfer pricing intensity (TPI). It means that the more foreign operations, the higher the transfer pricing through RPTAL and TPI.

\section{$\mathrm{H}_{5}$ : Foreign operation has a significant positive effect on transfer pricing through measure of RPTAL. \\ $\mathrm{H}_{6}$ : Foreign operation has a significant positive effect on transfer pricing through measure of TPI}

Management uses transfer pricing as a profit shift mechanism between companies to raise management bonuses (Chan et al., 2015). Research by Nazihah et al. (2019) has found a substantial positive correlation to the transfer pricing incentive system to optimize bonuses. A study by Nazihah et al. (2019) has identified a significant positive relationship between the incentive system and transfer pricing to optimize bonuses. In line with the bonus plan hypothesis of Watts \& Zimmermann (1986), if managers' bonuses depend on company's net income, they can increase bonuses by reporting the highest possible net profits in certain period to receive an increased bonus.

The owner's goal is to raise company income, while the management intends to earn a bonus by meeting the profit target through profit manipulation to increase salaries or benefits (Indrasti, 2016). Management may use transfer pricing to aggressively circumvent taxes to maximize revenues and to earn bonuses optimally. The transfer pricing implementation can be evaluated using related party transactions of assets and liabilities (RPTAL) and transfer pricing intensity (TPI). It means that the higher the bonus mechanism, the higher the transfer price using RPTAL and TPI. 
$\mathrm{H}_{7}$ : Bonus mechanism has a significant positive effect on transfer pricing through measure of RPTAL.

$\mathrm{H}_{8}$ : Bonus mechanism has a significant positive effect on transfer pricing through measure of TPI

Management's discretion is limited in many agreements by setting minimum and maximum thresholds in various accounting ratios and other company-related variables (Mariano \& Tribó 2015). According to Mariano \& Tribó (2015), companies' high growth prospects are demonstrated by their low leverage ratios. The hypothesis of the debt covenant in Watts \& Zimmerman's (1986) positive accounting theory notes that the more liable companies to debt breach contracts, the more likely managers are to select accounting methods that will maximize profits. The more companies use their debt to fund their enterprises, the lower the effective tax rate (Taylor, Richardson, \& Lanis, 2015).

Debt covenants or debt contracts may be measured by leverage ratio. Merle et al. (2019) from France found that increasing leverage using DER would affect higher transfer pricing. Nuradila \& Wibowo (2018) research has found a positive and significant influence of the debt covenant on rising transfer pricing. Companies tend to pay lenders' interest. Interest charges to lenders are allowable costs in the statement of revenue (Waworuntu \& Hadisaputra, 2016). Companies prefer to pay loan interest to lenders because payments of interest to creditors are allowed expenditures in the income statement (Waworuntu \& Hadisaputra, 2016). It suggests that the more debt-covenant rises, the more aggressive transfer pricing using RPTAL and TPI.

H9: Debt convenant has a significant positive effect on transfer pricing through measure of RPTAL.

$\mathrm{H}_{10}$ : Debt convenant has a significant positive effect on transfer pricing through measure of TPI.

\section{METHOD, DATA, AND ANALYSIS}

This study is a quantitative research that performs hypothesis testing. This research uses secondary data from annual reports and financial reports from manufacturing firms listed on the Indonesia Stock Exchange (IDX) for 2014-2018 through access to the database at www.idx.co.id and sample companies' official websites. This research is a study of panel data which incorporates data from time series and cross-sections.

\section{Population and Sample}

Based on the predetermined criteria, 24 manufacturing companies with an analytical duration of 5 years received 120 units of analysis. The following criteria were used for the purposeful sampling technique:

1. Having transactions of assets and liabilities, which also include foreign transactions.

2. To have at least 20 percent of foreign shareholders, directly or indirectly, as the controlling party for tunneling purposes.

3. Not currently receiving tax compensation.

\section{Data analysis technique}

This study incorporates quantitative research methods using the panel regression analysis, which integrates time series data with spaces and locations (cross-section). The methodology of data analysis is descriptive and inferential statistical analysis. The characteristics of the study variables are individually defined with descriptive statistical 
analysis. The analytical methods used are minimum value, maximum value, mean and standard deviation. Inferential statistical analysis is used to evaluate the research hypothesis, which has been formulated based on a framework.

\section{Measurement}

\section{Dependent Variable (Y)}

In this analysis, the measurement of the dependent variable uses two different measures:

a. Related Party Transaction Assets and Liabilities (RPTAL)

The estimation of the transfer pricing refers to research conducted by Utama (2015) using the following formula:

\section{b. $\quad$ Transfer Pricing Intensity (TPI)}

$$
\text { RPTAL }=\frac{\text { RelatedPartyTransactionAssets } \wedge \text { Liabilities }}{\text { TotalEquity }}
$$

In this analysis the second measurement of transfer pricing refers to Merle et al. (2019) research with the following formula:

\section{Independent Variable $(X)$}

$$
\mathrm{TPI}=\frac{\text { RelatedPartyTransactionReceivables }}{\text { TotalReceivables }}
$$

\section{a. Tunneling Incentive}

The indicator of business tunneling can be seen from the sum of receivables under the same parent company and other subsidiaries under the control of the same parent company, then compared to the assets held by the company in compliance with the measures defined by Tang (2016), with the following formula:

$$
\text { Tunneling Incentive }=\frac{\text { Relatedaccountreceivable }}{\text { TotalAset }}
$$

\section{b. Corporate Governance Mecanism}

This measurement relates to Pratama's (2020) research by measuring the number of commissioners. The Board of Commissioners also decides how corporate tax administration works as part of corporate governance (Permana \& Zulaikha, 2015).

\section{c. Foreign Operation}

The variables in this analysis are based on the same proxies as Pratama (2020) with the following formula:

\section{d. Bonus Mechanism}

$$
\text { Foreign Ownership }=\frac{\text { TotalSharesownedbyForeign }}{\text { TotalOutstandingShares }} \times 100 \%
$$

The same measurements as Refgia et al. (2017) are used in this analysis, with the following formula:

\section{e. Debt Convenant}

$$
\text { ITRENDLB }=\frac{\operatorname{NetIncome}(t)}{\operatorname{NetIncome}(t-1)} \times 100 \%
$$
formula:

The measurement of this research refers to Indrasti (2016) using the following

$$
\mathrm{DER}=\frac{\text { totalliabilities }}{\text { TotalEquity }}
$$




\section{RESULTS}

\section{Descriptive statistics}

The descriptive statistical analysis aims at providing a summary or a description of the data illustrated in the average, maximum, minimum, and standard deviation values of each variable. The descriptive statistical test results in this study found that each study variable shows a relatively large standard deviation.

Table 1. Descriptive Statistics

\begin{tabular}{lccccc}
\hline \multicolumn{1}{c}{ Variable } & N & Minimum & Maximum & Mean & Std Deviation \\
\hline RPTAL & 120 & 0,0000510 & 3,813583 & 0,274917 & 0,614297 \\
TPI & 120 & 0,0000461 & 0,978904 & 0,222152 & 0,269619 \\
Tunneling Incentive & 120 & 0,0000026 & 0,227161 & 0,047101 & 0,063529 \\
Corporate Governance Mechanism & 120 & 3,000000 & 9,000000 & 5,400000 & 1,530639 \\
Foreign Operation & 120 & 0,000000 & 0,974900 & 0,528068 & 0,302123 \\
Bonus Mechanism & 120 & $-0,968398$ & 52,96000 & 2,069089 & 5,706676 \\
Debt Convenant & 120 & 0,080000 & 7,990000 & 1,091034 & 1,159568 \\
\hline Soure: Seci
\end{tabular}

Source: Secondary data processed using EViews v.11, 2020

Based on the statistical results in Table 1, the minimum and maximum RPTAL values show that the organization minimizes and optimizes transfer pricing. The average value of the RPTAL transfer pricing indicates $27.49 \%$. It means that there is a relatively high potential for transfer pricing from asset and liability transactions over 25 percent of total equity. The standard deviation of transfer pricing using RPTAL is greater than the average value of 0.614297 , suggesting that data of transfer pricing using RPTAL has a broad data distribution. In the meantime, the TPI measure indicates an average transfer pricing of 0.222152. It means that the potential for the transfer pricing of credit purchase transactions contributes to receivables of $22.21 \%$, which are reasonably high. The standard deviation value of transfer pricing using TPI is greater than the average of 0.269619 , indicating that TPI data has a relatively large data distribution.

The average value of tunneling incentives indicates that the average sample company has 0.047101 or $4.71 \%$ of tunneling incentives. The average value of the mechanism for corporate governance as measured by the number of commissioners' boards is 5.4 . It means that the average sample company has more than five boards of commissioners. Meanwhile, the mean statistical variable for foreign transactions proxied by foreign ownership shares has an average value of 0.528068 , implying that the sample average is foreign business. As shown in Table 1, the average bonus mechanism is 2,069089. It is based on the net profit trend index calculation, suggesting that the business samples had a profit increase of $200 \%$. The last variable, debt covenant, has an average value of 1.091034. Debt covenant is measured based on total equity debt. This statistics shows that, on average, the companies have more debt than equity.

\section{Inferential Statistics}

Before testing the hypothesis, tests for the acceptable regression model of the three resulting models are needed, including the Common Effect Model (CEM), Fixed Effect Model (FEM), and Random Effect Model (REM). The model's selection is carried out in several stages, including the chow test, the Hausman test, and the Lagrange multiplier (LM) test. The best model's test results among the three models are shown in Tables 2, 3, and 4 . 
Jurnal Keuangan dan Perbankan

\begin{tabular}{lcccccc}
\hline Table 2. Chow Test Results & \multicolumn{3}{c}{ Regression Model 1 } & \multicolumn{3}{c}{ Regression Model 2 } \\
\hline Effects Test & Statistic & d.f. & Prob. & Statistic & d.f. & Prob. \\
Cross-section F & 45.977293 & $(23,91)$ & 0.0000 & 12.500779 & $(23,91)$ & 0.0000 \\
$\begin{array}{l}\text { Cross-section } \\
\text { Chi-square }\end{array}$ & 304.239976 & 23 & 0.0000 & 171.048470 & 23 & 0.0000
\end{tabular}

Source: Secondary data processed using EViews v.11, 2020

The chow test results in Table 2 for regression models 1 and 2 showed that the probability value of cross-section $\mathrm{F}$ was 0.0000 lower than the specified level of significance, $\mathrm{a}=5 \%$. H0 is therefore rejected, and H1 accepted. Based on the chow test, FEM is the most suitable model between CEM and FEM.

Table 3. Hausman Test Results

\begin{tabular}{lcccccc}
\hline & \multicolumn{3}{c}{ Regression Model 1 } & \multicolumn{3}{c}{ Regression Model 2 } \\
\hline Test Summary & Chi-Sq. & Chi-Sq. d.f. & Prob. & $\begin{array}{c}\text { Chi-Sq. } \\
\text { Statistic }\end{array}$ & $\begin{array}{c}\text { Chi-Sq. } \\
\text { d.f. }\end{array}$ & Prob. \\
$\begin{array}{l}\text { Cross-section } \\
\text { random }\end{array}$ & 12.280979 & 5 & 0.0311 & 5.232470 & 5 & 0.3882 \\
\hline
\end{tabular}

Source: Secondary data processed using EViews v.11, 2020

The Hausman test was also performed on the two regression models to determine the best model between FEM and REM. Table 3 shows the different Hausman test results in regression models 1 and 2. The value of cross-section F in Regression Model 1 is 0.0311 , which is lower than the $5 \%(\alpha=0.05)$, so H0 is rejected and H1 is accepted. Based on the Hausman test, the FEM is a panel data regression model most suitable for RPTAL (Model 1) between the FEM and the REM. Thus, the appropriate regression model in Model 1 is complete so that the Lagrange test does not proceed. Although in regression model 2, the transfer pricing regression with TPI is higher than $5 \%(\alpha=0.05)$ with a cross-section F value of $0.3882, \mathrm{H} 0$ is accepted, and H1 is rejected. REM is the panel data regression model for the most suitable FEM-REM moderating variable. Thus, model 2 regression testing continues to Lagrange testing.

Table 4.Test Results of Langrange Regression Model 2

\begin{tabular}{lccc}
\hline \multicolumn{4}{c}{ Test Hypothesis } \\
\hline & Cross-section & Time & Both \\
Breusch-Pagan & 103.4820 & 0.335065 & 103.8170 \\
& $(0.0000)$ & $(0.5627)$ & $(0.0000)$ \\
\hline
\end{tabular}

Source: Secondary data processed using EViews v.11, 2020

Table 4 shows that the cross-section value for $\mathrm{F}$ is 0.0000 or less than the significance of 5 percent $(\alpha=0.05)$. H0 is rejected, and $\mathrm{H} 1$ is accepted, meaning that the panel data regression model of transfer pricing regression model based on the Lagrange test using TPI (model 2) is better matched to REM and FEM. H0 is then rejected, and H1 accepted, which means that based on the Lagrange test, the panel data regression model for transfer pricing using a TPI (model 2) is the best model between REM and FEM.

The selected panel data regression model has passed the classical hypothesis test, consisting of a multicollinearity test and a heteroscedasticity test. The multicollinearity test indicates that the independent variables have no significant correlation. In park testing, possible heteroscedasticity in the Research Model was found. The Park test results suggest that the residual variation is constant or homoscedasticity from one observation to another. 
Jurnal Keuangan dan Perbankan

Once the most suitable regression model has been developed, hypothesis testing is performed. The t-test is used to evaluate the independent variables, which partially significantly influence the dependent variable. The FEM t-test findings for Model 1 are shown in Table 5, and the Random Effect Model (REM) results for Model 2 are shown in Table 6. Table 5 presents the outcomes of the t-test with the Fixed Effect Model (FEM), while Table 6 presents the effects of the t-test with the Random Effect Modell (REM).

Table .5 t-test results of FEM Model 1

\begin{tabular}{lcccc}
\hline \multicolumn{1}{c}{ Variable } & $\begin{array}{c}\text { Predicting } \\
\text { Sign }\end{array}$ & Coefficient & $\begin{array}{c}\text { Prob. } \\
\mathbf{a = 5 \%}\end{array}$ & Outcome \\
\hline Tunneling Incentive & + & 2.206873 & 0.0000 & H1 accepted \\
Corporate Governance Mechanism & - & -0.059396 & 0.0353 & H3 accepted \\
Foreign Operation & + & 0.289572 & 0.0440 & H5 accepted \\
Bonus Mechanism & + & $-1.75 E-05$ & 0.9930 & H7 rejected \\
Debt Convenant & + & 0.227746 & 0.0000 & H9 accepted \\
\hline Root MSE & 0.093888 & R-squared & 0.976444 \\
Mean dependent var & 0.274917 & Adjusted R-squared & 0.969196 \\
S.D. dependent var & 0.614297 & S.E. of regression & 0.107816 \\
Akaike info criterion & -1.410089 & Sum squared resid & 1.057801 \\
Schwarz criterion & -0.736445 & Log likelihood & 113.6054 \\
Hannan-Quinn criter. & -1.136519 & F-statistic & 134.7195 \\
Durbin-Watson stat & 1.804581 & Prob(F-statistic) & 0.000000 \\
\hline Source: Secondary & &
\end{tabular}

Source: Secondary data processed using EViews v.11, 2020

Based on Table 5, for the determinants of transfer pricing with RPTAL measures, the regression equation Model 1 is as follows:

\section{RPTAL $=0.090354+2.206873 \mathrm{TI}-0.059396 \mathrm{COM}+0.289572 \mathrm{FO}-$ 1.75E-05 ITRENDLB - 0.227746 LEV + e}

Meanwhile, for the determinants of transfer pricing with TPI measures, the regression equation Model 2 is as follows:

$$
\begin{aligned}
\text { TPI }= & 0.032974+3.848263 \mathrm{TI}+0.015940 \mathrm{COM}-0.081644 \mathrm{FO}- \\
& 0.000203 \text { ITRENDLB }-0.008784 \mathrm{LEV}+\mathrm{e}
\end{aligned}
$$

Table 6. t-test results of REM Model 1

\begin{tabular}{lcccc}
\hline \multicolumn{1}{c}{ Variable } & $\begin{array}{c}\text { Predicting } \\
\text { Sign }\end{array}$ & Coefficient & $\begin{array}{c}\text { Prob. } \\
\mathbf{a = 5}\end{array}$ & Outcome \\
\hline Tunneling Incentive & + & 3.848263 & 0.0000 & H2 accepted \\
Corporate Governance Mechanism & - & 0.015940 & 0.3012 & H4 rejected \\
Foreign Operation & + & -0.081644 & 0.2995 & H6 rejected \\
Bonus Mechanism & + & -0.000203 & 0.8973 & H8 rejected \\
Debt Convenant & + & -0.008784 & 0.5589 & H10 rejected \\
\hline \multicolumn{2}{c}{ Weighted Statistics } & & \\
\hline Root MSE & 0.085504 & R-squared & & 0.619584 \\
Mean dependent var & 0.063765 & Adjusted R-squared & & 0.602899 \\
S.D. dependent var & 0.139212 & S.E. of regression & & 0.087726 \\
Sum squared resid & 0.877321 & F-statistic & & 37.13433 \\
Durbin-Watson stat & 1.285251 & Prob(F-statistic) & & 0.000000 \\
\hline
\end{tabular}

Source: Secondary data processed using EViews v.11, 2020

Based on the panel data regression, the effects from the adjusted r-squared in model 1 of regression use the fixed-effect model of 0.969196. In regression model 1, the independent variables will describe the dependent variable by $96.91 \%$. Meanwhile, 
regression model 2 using the selected random effect model resulted in an adjusted Rsquared of 0.602899 . the independent variables can only describe the dependent variable simultaneously by 60.29 percent.

\section{Discussion}

\section{The Effect of Tunneling Incentive on Transfer Pricing}

Based on the hypothesis of the tunneling incentive in models 1 and 2, tunneling incentive has been proven to have a positive effect on transfer pricing. $\mathrm{H} 1$ and $\mathrm{H} 2$ are then accepted. Jensen and Meckling's (1976) agency theory reveals a relationship between different parties, which is consistent with this study. The control of the parent company in the group implies tunneling underlies the company's transfer pricing with RPTAL to avoid taxes and produce a significant profit. The data reveal a continued reduction in tunneling incentives from parent companies, accompanied by a decrease in transfer pricing using RPTAL. It is consistent with the second model using the TPI proxy. According to Susanti \& Firmansyah (2018), the controlling party's influence will trigger tunneling activities for group companies. The decline in tunneling incentives is also aligned with the low average transfer pricing using TPI in model 2.

This study supports Jensen \& Meckling (1976)'s agency theory on how conflicts are triggered by a conflict of interest among agents and shareholders. Majority shareholders with a large number of shares can have increasingly strong influence in determining relevant policies. One of the relevant policies is tunneling by asset transfers which favor the majority shareholders. The research findings by Lestari \& Solikhah (2019), Jafri \& Mustikasari (2018) and Saraswati \& Sujana (2017) proved major positive effects of tunneling incentive on transfer pricing. Tunneling is an act of unreasonably exploiting company funds (Niazi, Qazi, \& Basit, 2019). One explanation for tunneling incentives is to manipulate earnings of specific partnership groups to shift profits from higher tax rates to low-tax rates country for tax avoidance.

\section{The Effect of Corporate Governance Mechanism on Transfer Pricing}

Good corporate governance is one of the keys to business success and longevity (Purnamawati et al., 2017). The results of the hypothesis test show that the corporate governance mechanism has a significant negative effect on transfer pricing in model 1, so $\mathrm{H} 3$ is accepted. In order to avoid such opportunistic activities such as transfer pricing, the board of directors plays a role in supervising management. The implementation of a corporate governance mechanism is in line with the Jensen and Meckling (1976) agency theory, which states that shareholders pay agency costs in order to create good corporate governance, such as management fees. The agent is considered to have properly exercised its authority to minimize fraud, such as transfer pricing. This research model 1 is in line with the findings of the Pratama (2020) study which states that good corporate governance proxied by the proportion of the board of commissioners.has a negative impact on transfer pricing.

Meanwhile, in Model 2, there is no significant influence of the corporate governance mechanism on TPI transfer pricing. Thus H4 is rejected. The number of commissioners does not correspond to the scale of the transfer pricing opportunity of accounts receivable transactions. It is possibly due to the regulations for the documentation of IAI-issued disclosures of relevant parties on transfer pricing by the Tax Directorate General and PSAK 7. The study findings on the impact of corporate governance mechanism in model 2 are consistent with Noviastika et al. (2016), suggesting good corporate governance has no significant effect on transfer pricing. Considering the shareholding aspect of Indonesian manufacturing firms, the directors can own shares in the companies they supervise. It 
encourages the board of directors' tacit intention to commit fraud to maximize income through tax avoidance. Furthermore, based on the modified R-squared Model 2, which is far less than Model 1. It is possible to evaluate other corporate governance structures and other variables that can impact TPI; while based on the modified R-squared model 2, which is considerably smaller than model 1 , other mechanisms of corporate governance and other variables can affect TPI.

\section{The Influence of Foreign Operations on Transfer Pricing}

Model 1 has a positive and significant impact on foreign operations' transfer pricing, so H5 is accepted. It is consistent with the findings of Pratama's (2020) study, which shows the positive and vital impact of foreign operations using foreign ownership on transfer pricing. The company's increased foreign ownership makes it easier to make different transactions for the majority shareholder to maximize their benefit. This action is to generate the ideal profit according to the company's objectives. Companies with affiliates abroad undertake foreign market operations to reduce tax burdens using a transfer pricing scheme.

Different from Model 1, foreign operations do not have a substantial impact on TPI. H6 is therefore rejected. Model 2 does not influence the level of transfer pricing conducted by manufacturing companies in Indonesia regardless of the foreign operation scale. Foreign operations measured by foreign share ownership do not impact the future transfer pricing scale for transactions that trigger debts with related parties abroad. The findings are supported by Septiyani et al. (2018), which shows no relationship between foreign ownership and transfer pricing exists because the sample does not consider the proportion of particular relation transactions outside foreign ownership. The relationship between families, which can cause transactions between associated parties, is another thing to be considered. Based on the adjusted R-squared of model 2, which is significantly smaller than model 1, measurements and other variables in model 2 are still more likely to have a significant influence on the TPI.

\section{The Effect of Bonus Mechanism on Transfer Pricing Decisions}

The bonus mechanism in Model 1 and Model 2 does not impact Indonesian manufacturing companies in implementing transfer pricing policies, and thus $\mathrm{H} 7$ and $\mathrm{H} 8$ are rejected. The bonus scheme hypothesis in Watts \& Zimmerman's (1986) positive accounting theory notes that businesses have opted for accounting procedures to maximize profit to get bonuses in the current year is not confirmed by this study's findings. Based on the growth in manufacturers' gross annual profit, their annual profit was not significantly increased. Based on the increase in manufacturers' yearly average profit, their annual profit has not increased considerably. Moreover, based on Indonesian manufacturing firms' characteristics, an effective mechanism for corporate governance with most of commissioners meeting requirements and with overstating profits of bonus mechanism is still very rare. This study's findings support research by (Susanti \& Firmansyah 2018), showing that the bonus mechanism does not affect transfer pricing. If companies shift profits to related enterprises, the effects decrease bonuses and deteriorate the company's reputation through an opportunistic act such as aggressive tax avoidance by transfer pricing.

\section{The Effect of Debt Covenants on Transfer Pricing}

Hypothesis testing in Model 1 shows that debt covenant positively affects transfer pricing with RPTAL, so that H9 is accepted. The Watts \& Zimmerman (1986) debt contract theory confirms model 1 . The higher the debt covenant, the closer the limitations of the debt agreement, so that the greater the risk of the rule violation and technical failure costs. 
Managers will prefer accounting methods to maximize profit to reduce the risk of loss. Transfer pricing is one of the accounting techniques used by companies in increasing earnings. A study by Merle et al. (2019) supports this report's findings, suggesting that leverage using DER has a substantial positive impact on transfer pricing. The higher the leverage ratio in the company, the more likely transfer pricing occurs.

Meanwhile, in model 2, the debt covenant has no significant effects on the transfer pricing through TPI. The tenth hypothesis is thus rejected in this study. The findings of this analysis support research by Indrasti (2016), which explores the relationship between debt covenant and transfer pricing. Based on study findings on sample manufacturing firms, such companies do not carry out transfer pricing to raise profits by loosening up an agreement limit or a credit regulation in a debt covenant. It is reflected in the profit increase statistics for sample companies, which shows no extremely high-profit growth. Furthermore, based on the adjusted R-squared model 2, independent variables can only affect transfer pricing with a much smaller percentage than Model 1, so that other measurements could possibly explain the transfer pricing.

\section{CONCLUSION, LIMITATIONS, AND SUGGESTIONS}

\section{Conclusion}

Research shows that the transfer pricing from asset and liability transactions (RPTAL) is higher than total equity above $25 \%$, but data for five years show a decreasing trend. In the meantime, transfer pricing with a TPI of $22,21 \%$ indicates that the potential for transfer pricing for transactions where receivables occur remains relatively high. The Finance Minister Regulation No 22/PMK.03/2020 on the procedures for implementing Advance Pricing Agreement is intended to encourage healthier transfer pricing practices. The disclosure of related parties is also mandatory for companies as regulated in PSAK 7 issued by IAI.

This study investigated factors that influence transfer pricing by comparing two models in two models. Model 1 used the Proxy of Related Party Transaction Assets and Liabilities (RPTAL) to explain transfer pricing potential both inflows and outflows. The inflows illustrate the potential for transfer pricing on foreign-related parties from the influx of goods/services, such as purchases, while the outflow demonstrates the potential for transfer pricing from the flow of commodities/services such as sales. Meanwhile, model 2 uses Transfer Pricing Intensity (TPI) was a proxy to demonstrate the potential for outflow transfer pricing.

Therefore, it is recommended to measure transfer pricing using the RPTAL because it yields more comprehensive outcome. The difference in the measurement scope produces different results in model 1 and model 2. Research findings in Model 1 suggest that tunneling incentives, foreign operations, and debt covenants significantly influence transfer pricing. The corporate governance mechanism has a significant negative effect on transfer pricing with RPTAL, while the bonus mechanism does not substantially impact transfer pricing with RPTAL. The research results in Model 2 indicate that tunneling incentives have a substantial positive effect on transfer pricing while the corporate governance mechanism, foreign operation, bonus mechanism, and debt covenant have no significant influence on transfer pricing with TPI. For model 1, the independent variables will simultaneously affect the dependent variable by $96.6 \%$, while in model 2, only $60.2 \%$. In conclusion, the transfer pricing in model 1 more explores the significances of the independent variables rather than the dependent variables. 


\section{Limitations and suggestions}

It is suggested that companies should always comply with relevant transfer pricing regulations to avoid tax penalties. The substantial supervision by tax authorities is considered necessary to reduce unhealthy transfer pricing practices. Therefore, further research should use factors other than variable of company, such as transfer pricing policies and fiscal surveillance, which are not addressed in this study. Future studies should explore different sectors such as the mining industry. The mining sector is recommended due to the frequent occurence of foreign related party transactions across countries. Therefore there is a big likelihood of transfer pricings to avoid tax aggressively.

\section{REFERENCES}

Amidu, M., Coffie, W., \& Acquah, P. (2017). Transfer pricing, earnings management and tax avoidance of firms in Ghana. Journal of Financial Crime, 1-26.

Armstrong, C. S., Blouin, J. L., Jagolinzer, A. D., \& Larcker, D. F. (2015). Corporate governance, incentives, and tax avoidance. Journal of Accounting and Economics, 60(1), 1-17. https:// doi.org/10.1016/j.jacceco.2015.02.003

Azzura, C. S., \& Pratama, A. (2019). Influence of Taxes, Exchange Rate, Profitability, and Tunneling Incentive on Company Decisions of Transferring Pricing. Jurnal Akuntansi Berkelanjutan Indonesia, 2(1), 123. https://doi.org/10.32493/jabi.v2i1.y2019.p123-133

Borge, M.Z, Byberg, K., Schindler, D., \& Hopland, A. O. (2018). The Tightness of Countryspecific Income Shifting Regulation and Multinationals' Transfer Pricing: : an empirical study of European multinational corporations and their majority-owned affiliates worldwide. Master Thesis. NHH Brage. retreived from https://openaccess.nhh.no/nhh-xmlui/handle/11250/2585905.

Chan, K. H., Lo, A. W. Y., \& Mo, P. L. L. (2015). An empirical analysis of the changes in tax audit focus on international transfer pricing. Journal of International Accounting, Auditing and Taxation, 24, 94-104. https://doi.org/10.1016/j.intaccaudtax.2014.12.001

Cheung, Y. L., Jing, L., Lu, T., Rau, P. R., \& Stouraitis, A. (2009). Tunneling and propping up: An analysis of related party transactions by Chinese listed companies. Pacific Basin Finance Journal, 17(3), 372-393. https:/ / doi.org/10.1016/j.pacfin.2008.10.001

Cristea, A. D., \& Nguyen, D. X. (2016). Transfer Pricing by Multinational Firms: New Evidence from Foreign Firm Ownerships. American Economic Journal: Economic Policy, 8(3), 170 - 202. Retrieved from http://dx.doi.org/10.1257/pol.20130407

Davies, R. B., Martin, J., Parenti, M., Toubal, F., Behrens, K., Cline, R., Conconi, P., Cristea, A., Eden, L., Egger, P., Fontagné, L., Gresik, T., Hines, J., \& Legros, P. (2016). Knocking on Tax Haven's Door: Multinational Firms and Transfer Pricing. 613504.

Direktorat Jenderal Pajak. (2018). Lakin Djp. Laporan Kinerja Direktorat Jenderal Pajak 2018, 1-118. https:/ / www.pajak.go.id/sites/default/files/2019-05/LAKIN DJP 2018.pdf

El-Helaly, M. (2018). Related-party transactions: a review of the regulation, governance and auditing literature. Managerial Auditing Journal. Retrieved from https://doi.org/10.1108/MAJ-07-2017-1602

Falahat, M., \& Migin, M. W. (2017). Export performance of international new ventures in emerging market. International Journal of Business and Globalisation, 19(1), 111. https://doi.org/10.1504/ijbg.2017.10005602 
Jurnal Keuangan dan Perbankan

Holtzman, Y. \& Nagel, P. (2014). An Introduction To Transfer Pricing. Journal of Management Development, 33(1), 57-61. DOI: 10.1108/JMD-11-2013-0139

Hu, H. W., \& Sun, P. (2019). What determines the severity of tunneling in China? Asia Pacific Journal Management, 36, 161 - 184. Retrieved from https://doi.org/10.1007/s10490-018-9582-z

Indrasti, A. W. (2016). Pengaruh Pajak, Kepemilikan Asing, Bonus Plan dan Debt Covenant Terhadap Keputusan Perusahaan Untuk Melakukan Transfer Pricing (Studi Empiris Pada Perusahaan Manufaktur yang Terdaftar di Bursa Efek Indonesia Tahun 20122015). Jurnal Akuntansi, 9(6), 348-371. https://doi.org/10.1017/CBO9781107415324.004

Jafri, H. E., \& Mustikasari, E. (2018). Pengaruh Perencaan Pajak, Tunnneling Incentive dan Aset Tidak Berwujud Terhadap Perilaku Transfer Pricing pada Perusahaan Manufaktur yang Memiliki Hubungan Istimewa yang Terdaftar di Bursa Efek Indonesia Periode 2014-2016. Berkala Akuntansi Dan Keuangan Indonesia, 3(2), 63. https://doi.org/10.20473/baki.v3i2.9969

Jensen, M. C., \& Meckling, W. H. (1976). Theory of The Firm: Managerial Behavior, Agency Costs and Ownership Structure. Journal of Financial Economics 3, 3, 305-360.

Lestari, J. \& Solikhah, B. (2019). The Effect of CSR, Tunneling Incentive, Fiscal Loss Compensation, Debt Policy, Profitability, Firm Size to Tax Avoidance. Accounting Analysis Journal, 8(1), 31-37. DOI 10.15294/aaj.v8i1.23103

Lin, C. W., \& Chang, H. C. (2010). Motives of transfer pricing strategies - Systemic analysis. Industrial Management and Data Systems, 110(8), 1215-1233. https://doi.org/10.1108/02635571011077843

Lo, A. W. Y., Wong, R. M. K., \& Firth, M. (2010). Tax, financial reporting, and tunneling incentives for income shifting: An empirical analysis of the transfer pricing behavior of Chinese-listed companies. Journal of the American Taxation Association, 32(2), 1-26. https://doi.org/10.2308/jata.2010.32.2.1

Mariano, B., \& Tribó Giné, J. A. (2015). Creditor Intervention, Investment, and Growth Opportunities. Journal of Financial Services Research, 47(2), 203-228. https://doi.org/10.1007/s10693-013-0188-9

Martins, A. F. (2017). Accounting information and its impact in transfer pricing tax compliance: a Portuguese view. EuroMed Journal of Business, 12(2), 207-220. https://doi.org/10.1108/EMJB-11-2016-0029

Merle, R., Al-Gamrh, B., \& Ahsan, T. (2019). Tax havens and transfer pricing intensity: Evidence from the French CAC-40 listed firms. Cogent Business and Management, 6(1), 1-12. https://doi.org/10.1080/23311975.2019.1647918

Minnick, K., \& Noga, T. (2010). Do corporate governance characteristics influence tax management? Journal of Corporate Finance, 16(5), 703-718. https://doi.org/10.1016/j.jcorpfin.2010.08.005

Mispiyanti. (2015). Pengaruh Pajak, Tunneling Incentive dan Mekanisme Bonus terhadap Keputusan Transfer Pricing. Jurnal Akuntansi \& Investasi, 16(1), hal. 62-73.

Nazihah, A., Azwardi, \& Fuadah, L. L. (2019). The Effect Of Tax, Tunneling Incentive, Bonus Mechanisms, And Firm Size On Transfer Pricing (Indonesian Evidence). Journal of Accounting Finance and Auditing Studies (JAFAS), 5(1), 1-17. 
https://doi.org/10.32602/jafas.2019.0

Nguyen, N. T. (2019). The Relationship between FDI Enterprise Earnings and Signs of Transfer Pricing. Journal of Sustainable Development, 12(4), 99. https://doi.org/10.5539/jsd.v12n4p99

Niazi, A. A., Qazi, T. F., \& Basit, A. (2019). Expounding the Structure of Slyer Ways of Tunneling in Pakistan. Global Regional Review, IV(II), 329 - 343. doi:10.31703/grr.2019(IV-II).35

Noviastika, D., Mayowan, Y., \& Karjo, S. (2016). Pengaruh Pajak, Tunneling Incentive Dan Good Corporate Governance (GCG) Terhadap Indikasi Melakukan Transfer Pricing Pada Perusahaan Manufaktur Yang Terdaftar Di Bursa Efek Indonesia (Studi Pada Bursa Efek Indonesia Yang Berkaitan Dengan Perusahaan Asing). Jurnal Perpajakan, $8(1), 1-9$.

Nuradila, R. F., \& Wibowo, R. A. (2018). Tax Minimization sebagai Pemoderasi Hubungan antara Tunneling Incentive, Bonus Mechanism dan Debt Convenant dengan Keputusan Transfer Pricing. Journal of Islamic Finance and Accounting, 1(1). https:// doi.org/10.22515/jifa.v1i1.1135

Permana, A. R. D., \& Zulaikha. (2015). Pengaruh corporate Governance Terhadap Penghindaran Pajak (Studi Empiris pada Perusahaan Manufaktur yang Terdaftar di Bursa Efek Indonesia 2011-2014). Diponegoro Journal of Accounting, 4(4), 1-11.

Pratama, A. (2020). Corporate governance, foreign operations and transfer pricing practice: The case of Indonesian manufacturing companies. International Journal of Business and Globalisation, 24(2), 185-200. https:/ / doi.org/10.1504/IJBG.2020.105167

Purnamawati, I. G. A., Yuniarta, G. A., \& Astria, P. R. (2017). Good Corporate Governance Dan Pengaruhnya Terhadap Nilai Perusahaan Melalui Corporate Social Responsibility Disclosure. Jurnal Keuangan Dan Perbankan, 21(2), 276-286. https://doi.org/10.26905/jkdp.v21i2.505

Refgia, T., Ratnawati, V., \& Rusli. (2017). Pengaruh Pajak, Mekanisme Bonus, Ukuran Perusahaan, Kepemilikan Asing, dan Tunneling Incentive Terhadap Transfer Pricing (Perusahaan Sektor Industri Dasar Dan Kimia Yang Listing Di BEI Tahun 2011-2014). Jurnal Online Mahasiswa Fakultas Ekonomi Universitas Riau, 4(1), 543-555.

Robu, I. B., \& Căpățină-Verdeș, N. (2017). „The assessment of the transfer pricing influence on the income tax through the net margin method, in the case of the companies listed on the Bucharest Stock Exchange". In Proceedings of the 12th International Conference Accounting and Management Information Systems (pp. 262-275).

Rosadi, F. (2019). Mengejar Lompatan Rasio: Fenomena Tax Ratio Indonesia. Media Keuangan, 15(138) 3-53. Jakarta: Sekretariat Jendral Kementrian Keuangan.

Saraswati, G. A. R. S., \& Sujana, I.K. (2017). Pengaruh Pajak, Mekanisme Bonus, Dan Tunneling Incentive Pada Indikasi Melakukan Transfer Pricing. E-Jurnal Akuntansi, 19, 1000-1029.

Septiyani, R. P. P., Ramadhanti, W., \& Sudibyo, Y. A. (2018). Some Factors That Affect Transfer Pricing Decision. SAR (Soedirman Accounting Review) : Journal of Accounting and Business, 3(1), 21. https:// doi.org/10.20884/1.sar.2018.3.1.1158

Setiawan, H. (2014). Transfer Pricing dan Risikonya Terhadap Penerimaan Negara. 
https://doi.org/10.1017/CBO9781107415324.004

Sikka, P., \& Willmott, H. (2010). The dark side of transfer pricing: Its role in tax avoidance and wealth retentiveness. Critical Perspectives on Accounting, 21(4), 342-356. https://doi.org/10.1016/j.cpa.2010.02.004

Sofiati, S. A., \& Zulaikha. (2018). Analisis Pengaruh Tata Kelola Perusahaan dan Kompensasi Eksekutif Terhadap Agresivitas Pajak (Studi Empiris pada Perusahaan Nonkeuangan yang Terdaftar di Bursa Efek Indonesia Tahun 2013-2016). Diponegoro Journal of Accounting, 7(4), 1-14.

Solikhah, B., \& Suryarini, T. (2020). Perpajakan. UNNES Press: Semarang Indonesia.

Suryarini, T., Mega C.A., \& Hidayah, R. (2020). The Effect of Tunneling Incentive to Transfer Pricing Decision with Tax Minimization As a Moderating Variable. KnE Social Sciences, 2020(2010), 1-13. https:/ / doi.org/10.18502/kss.v4i6.6584

Susanti, A., \& Firmansyah, A. (2018). Determinants of transfer pricing decisions in Indonesia manufacturing companies. Jurnal Akuntansi $\mathcal{E}$ Auditing Indonesia, 22(2), 8193. https://doi.org/10.20885/jaai.vol22.iss2.art1

Tang, T.Y.H. (2016). Privatization, tunneling, and tax avoidance in Chinese SOEs. Asian Review of Accounting, 24(3), 274-234. https:/ / doi.org/10.1108/ARA-04-2012-0017

Taylor, G., Richardson, G., \& Lanis, R. (2015). Multinationality, Tax Havens, Intangible Assets, and Transfer Pricing Aggressiveness: An Empirical Analysis. Journal of International Accounting Research, 14(1), 25 - 57. Retrieved from https://doi.org/10.2308/jiar-51019

Utama, C. A. (2015). Penentu Besaran Transaksi Pihak Berelasi: Tata Kelola, Tingkat Pengungkapan, Dan Struktur Kepemilikan. Jurnal Akuntansi Dan Keuangan Indonesia, 12(1), 37-54. https://doi.org/10.21002/jaki.2015.03

Watts, R. L., \& Zimmerman, J. L. (1986). Positive accounting theory. Prentice-Hall.

Waworuntu, S. R., \& Hadisaputra, R. (2016). Determinants of Transfer Pricing Aggressiveness in Indonesia. Pertanika J. Soc. Sci. \& Hum., 24, 95-110.

Widyasari, P. A., Sutanto, C., \& Hastuti, M. E. (2019). Corporate life cycle, corporate governance structure, and corporate social responsibility disclosure. Jurnal Keuangan Dan Perbankan, 23(3), 385-402. https://doi.org/10.26905/jkdp.v23i3.2694

Yendrawati, R., \& Asy'ari, E. F. (2017). The Role of Corporate Governance as a Leverage Moderating and Free Cash Flow on Earnings Management. Jurnal Keuangan Dan Perbankan, 21(3), 412-424. https:// doi.org/10.26905/jkdp.v21i3.704

Yulia, A., Hayati, N., \& Daud, R. M. (2019). the Influence of Tax, Foreign Ownership and Company Size on the Application of Transfer Pricing in Manufacturing Companies Listed on Idx During 2013-2017. International Journal of Economics and Financial Issues, 9(3), 175-181. https://doi.org/10.32479/ijefi.7640 